\title{
Governance explains variation in national responses to the biodiversity crisis
}

\author{
ZACHARY BAYNHAM-HERD*1,2, TATSUYA AMANO ${ }^{1,3}$, WILLIAM J. SUTHERLAND ${ }^{1}$ AND \\ PAUL F. DONALD ${ }^{1,4}$ \\ ${ }^{I}$ Conservation Science Group, Department of Zoology, University of Cambridge, The David Attenborough Building, Pembroke Street, Cambridge \\ CB2 3QZ, UK, ${ }^{2}$ The University of Edinburgh, Institute of Geography, Drummond Street, Edinburgh EH8 9XP, UK, ${ }^{3}$ Centre for the Study of \\ Existential Risk, University of Cambridge, 16 Mill Lane, Cambridge CB2 1SG, UK and ${ }^{4}$ BirdLife International, The David Attenborough \\ Building, Pembroke Street, Cambridge, CB2 3QZ, UK
}

Date submitted: 31 January 2017; Date accepted: 29 October 2017; First published online 13 February 2018

\section{SUMMARY}

Growing concern about the biodiversity crisis has led to a proliferation of conservation responses, but with wide variation between countries in the levels of engagement and investment. Much of this variation is inevitably attributed to differences between nations in wealth. However, the relationship between environmentalism and wealth is complex and it is increasingly apparent that other factors are also involved. We review hypotheses that have been developed to explain variation in broad environmentalism and show that many of the factors that explain such variation in individuals, such as wealth, age and experience, also explain differences between nation states. We then assess the extent to which these factors explain variation between nation states in responses to and investment in the more specific area of biodiversity conservation. Unexpectedly, quality of governance explained substantially more variation in public and state investment in biodiversity conservation than did direct measures of wealth. The results inform assessments of where conservation investments might most profitably be directed in the future and suggest that metrics relating to governance might be of considerable use in conservation planning.

Keymords: Convention on Biological Diversity, environmentalism, governance, post-materialism, GDP, social science, psychology, priority setting

\section{INTRODUCTION}

It is axiomatic that concern for and investment in biodiversity conservation varies greatly both between individuals and

\footnotetext{
*Correspondence: Zachary Baynham-Herd email z.baynham-herd@ ed.ac.uk

Supplementary material can be found online at https://doi.org/ $10.1017 /$ S037689291700056X
}

between countries, yet the reasons for this variation remain elusive. The current biodiversity crisis has united the world's nations in attempts, thus far with mixed success, to address it (Butchart et al. 2010). It is apparent that the response to the problem is occurring at different rates in different countries and that simple economics are not the sole determinant of this variation. For example, richer countries spend more on conservation but have less biodiversity (McClanahan \& Rankin 2016) and nationallevel success in protecting threatened species is largely unrelated to wealth (Rodrigues et al. 2014). National conservation effort varies by region (Lindsey et al. 2017) and protected area cover appears to depend mainly upon an interaction between democratic strength and inequality (Kashwan 2017). A greater understanding of this variation in state-level responses to biodiversity conservation might help identify means to increase the prevalence of positive conservation efforts (and thereby contribute to Aichi Target 1 of the Convention on Biological Diversity Strategic Plan for Biodiversity 2011-2020; CBD 2010), as well as being useful in conservation planning (Eklund et al. 2011; Lindsey et al. 2017).

Although we are not aware of any single overriding theory to explain national-level variation in conservation responses, numerous hypotheses have been proposed to account for the adoption of more general concerns for the environment and pro-environmental behaviour ('environmentalism'), both between individuals and between states (Table 1). The underlying metrics of such analyses are usually factors such as energy use, recycling, responses to pollution, willingness to pay, aesthetic appreciation of nature or 'biospheric' values towards the environment (Steg \& Vlek 2009; Raymond \& Kenter 2016). Although there is much overlap, the literature examining individual-level variation in environmentalism focuses on personal characteristics and psychological variables such as attitudes, beliefs, values and norms (Schwartz 1992; Dietz et al. 2005; Schultz et al. 2005; Heberlein 2012). In contrast, national-level variation is usually explained by macro-level socioeconomic drivers (Pisano \& Lubell 2017). As the focus of this study is on national responses to conservation, we review these socioeconomic theories and use them as the basis of our analysis. 
Table 1 Some socioeconomic and societal correlates of broad environmentalism identified at national and individual levels. Numbers in parentheses in the first column link to those listed after the names of the explanatory variables in Table 2 to indicate which factor each explanatory variable was selected to represent in the models. GDP $=$ gross domestic product.

\begin{tabular}{|c|c|c|c|}
\hline Factor & $\begin{array}{l}\text { Relationship with } \\
\text { environmentalism }\end{array}$ & $\begin{array}{l}\text { National } \\
\text { (across countries) }\end{array}$ & $\begin{array}{l}\text { Individual } \\
\text { (mithin country) }\end{array}$ \\
\hline Wealth (1) & $\begin{array}{l}\text { Variable, generally } \\
\text { positive }\end{array}$ & $\begin{array}{l}\text { GDP or rate of economic development } \\
\text { (Gelissen 2007; Givens \& Jorgenson } \\
\text { 2011) }\end{array}$ & $\begin{array}{l}\text { Personal wealth relative to the national } \\
\text { average (Gelissen 2007; Franzen \& Vogl } \\
\text { 2013), but see Dunlap and York (2008) }\end{array}$ \\
\hline Trust (2) & Positive & Governance (Harring 2013) & $\begin{array}{l}\text { Interpersonal trust (Meyer \& Liebe 2010; } \\
\text { Franzen \& Vogl 2013) }\end{array}$ \\
\hline Post-materialism (3) & Positive & Post-materialism (Gelissen 2007) & $\begin{array}{l}\text { Post-materialist values (Gelissen 2007; } \\
\text { Franzen \& Vogl 2013; Gifford \& Nilsson } \\
\text { 2014), but see Davis (2000) }\end{array}$ \\
\hline Awareness (4) & Positive & $\begin{array}{l}\text { Media coverage of environmental } \\
\text { issues (Harring et al. 2011); national } \\
\text { levels of education (Ignatow 2006) }\end{array}$ & $\begin{array}{l}\text { Individual levels of education (Gelissen } \\
\text { 2007; Clements 2012; Franzen \& Vogl } \\
\text { 2013; Gifford \& Nilsson 2014) }\end{array}$ \\
\hline Autonomy/maturity (5) & Positive & $\begin{array}{l}\text { Years since independence (Hershfield } \\
\text { et al. 2014); autonomy, } \\
\text { self-expression (Dobewall \& Strack } \\
\text { 2014) }\end{array}$ & $\begin{array}{l}\text { Sense of control, age, political engagement } \\
\text { (Gelissen 2007; Clements 2012; Gifford \& } \\
\text { Nilsson 2014) }\end{array}$ \\
\hline Integration (6) & Positive & $\begin{array}{l}\text { Integration with world polity (Boli \& } \\
\text { Thomas 1997; Frank et al. 2000; } \\
\text { Givens \& Jorgenson 2013); perceived } \\
\text { country age (Hershfield et al. 2014) }\end{array}$ & $\begin{array}{l}\text { Sense of control; responsibility (Gifford \& } \\
\text { Nilsson 2014); civic cooperation (Owen \& } \\
\text { Videras 2006) }\end{array}$ \\
\hline $\begin{array}{l}\text { Environmental } \\
\text { experience }\end{array}$ & Positive & $\begin{array}{l}\text { Level of environmental degradation } \\
\quad \text { (Givens \& Jorgenson 2011) }\end{array}$ & $\begin{array}{l}\text { Childhood exposure to the environment; } \\
\text { proximity to environmental problems } \\
\text { (Gifford \& Nilsson 2014) }\end{array}$ \\
\hline $\begin{array}{l}\text { Religious or political } \\
\text { stance }\end{array}$ & Variable & $\begin{array}{l}\text { Religion (Hand \& Van Liere 1984); } \\
\text { political system (Nawrotzki 2012) }\end{array}$ & $\begin{array}{l}\text { Religion (Wolkomir et al. 1997; Clements } \\
\text { 2012; Manfredo et al. 2016); politics } \\
\text { (Sapiains et al. 2016) }\end{array}$ \\
\hline
\end{tabular}

\section{The roots of environmentalism}

At least three (not mutually exclusive) theories have been proposed to explain the development of broad environmentalism in terms of economic growth. Inglehart $(1995 ; 2000)$ proposed that environmental concerns and corresponding environmental behaviours are the results of post-materialistic values that are likely to be more prevalent in wealthier nations: once a certain level of economic security is met, individuals become free to develop post-materialistic values, which include support for movements such as feminism, human rights, animal welfare and environmentalism (Duroy 2008). The postmaterialist hypothesis receives empirical support from a number of studies that find a positive relationship between environmentalism and post-materialist values (Abramson 1997; Kidd \& Lee 1997). However, this link has been challenged (Dietz et al. 2005). For instance, Davis (2000) found no difference between post-materialists and materialists in their perceived personal efforts regarding conservation or general ecological concerns, while Fairbrother (2013) suggested that environmental concerns are highest in poorer nations. Inglehart (1995) also acknowledged that environmental concerns persist in poorer nations, but suggested that citizens of poorer countries develop environmental concerns over local issues that directly affect them, whereas in wealthy nations environmental concern is more likely to arise as an indirect consequence of affluence.

The prosperity hypothesis (Diekmann \& Franzen 1999) predicts that environmental concern increases with economic development as a direct consequence of greater income and not due to the development of new values. This hypothesis is based upon standard economic theory, which reasons that the restoration of a damaged environment is not only a collective good but also a superior good, for which demand rises with income (Franzen \& Meyer 2010). Consequently, there should be a positive correlation between a country's wealth and its level of environmental responsibility. This is supported by evidence that pro-environmental views and willingness to pay for environmental protection increase with wealth both within and between countries (Kemmelmeier et al. 2002; Franzen 2003; Franzen \& Meyer 2010).

Both the post-materialism and prosperity hypotheses are also used to support the environmental Kuznets curve (EKC) hypothesis, which proposes that whilst environmental degradation initially rises with increasing income per capita, degradation levels stabilize before declining at higher income levels (Grossman \& Krueger 1995; Dinda 2004). An EKC has been identified for some environmental metrics like energy 
use, emissions and water quality (Luzzati \& Orsini 2009; Orubu \& Omotor 2011; Apergis \& Ozturk 2015), but has been contested as an empirical illusion (Stern 2004) and fails to appear in other studies with the same or other environmental indicators (Koop \& Tole 1999; Kijima et al. 2010; Ozturk \& Al-Mulali 2015), including those related to conservation (Dietz \& Adger 2003; Mills \& Waite 2009).

All economic explanations of environmentalism face the inherent contradiction that while concern for the environment may increase with greater wealth, so too does environmental destruction, since economic development has been identified as one of the strongest correlates of biodiversity loss (Dietz et al. 2007; Bradshaw et al. 2010). Furthermore, these affluence-based hypotheses have been challenged by Dunlap and Mertig (1997) and Dunlap and York (2008), whose globalization hypothesis posits that environmental concerns are no longer confined to post-materialistic elites within wealthy nations and that there is no clear correlation between wealth and environmental concern.

Although none can be entirely divorced from economics, numerous other socioeconomic patterns have been proposed to explain environmentalism, both between and within nations (Table 1). Pinker (2011) argues that long-term declines in human violence can be linked to a number of 'civilizing' historical and social trends, such as the development of the modern nation state and its associated judiciary, the empowerment of women and advances in education. Closely following the trend of declining violence against humans, Pinker (2011) argues, is a decline in violence against animals and, perhaps in the longer term, this extends to a decline in violence against the environment. Pinker's (2011) ideas overlap with the principles of world polity theory that highlights the global cultural diffusion of accepted institutional structures and modes of thinking (Shandra 2007; Givens \& Jorgenson 2013) and how international organizations such as the UN fund and support domestic environmentalism as part of a 'world environmental regime' (Longhofer \& Schofer 2010). World polity theory might explain why even countries with negligible interests in environmental matters generally have a government department charged with overseeing such issues.

A nation's linkage to world society is a strong predictor of the number of international environmental treaties it has ratified (Frank 1999) and its level of environmental concern (Longhofer \& Schofer 2010). Global institutionalization of the principle that nations bear responsibility for environmental protection may be more influential in driving national conservation agendas than the domestic processes of increasing affluence or environmental degradation (Frank et al. 2000). Both Pinker's (2011) civilizing process and world polity theory require significant time over which to evolve, perhaps explaining why the age or perceived age of a country is positively correlated with environmentalism (Hershfield et al. 2014).

Developing an overarching theory may be problematic given that other historical (Grove 1996; Adams et al. 2004), political (Heath \& Gifford 2006; Sapiains et al. 2016) and religious traditions (White 1967; Hand \& Van Liere 1984) also shape environmental concerns and values both within and between countries (Manfredo et al. 2016). Moreover, the direction of predictors of environmentalism can vary across countries with different income levels (Nawrotzki 2012) or within countries over time (Kahn 2002; Franzen \& Vogl 2013). Furthermore, it appears that environmental concern does not always predict pro-environmental behaviour (Schultz et al. 2005; Steg \& Vlek 2009; Heberlein 2012; Everard et al. 2016).

We assess the performance of these key hypotheses developed to explain the variation in broad environmentalism for explaining country-level variation in the more specific area of biodiversity conservation. While the drivers of variation in responses to biodiversity and wildlife have been explored in local contexts (Johansson et al. 2013; Kansky et al. 2014) and predictors of broad environmentalism have been assessed at a multinational level (Gelissen 2007; Nawrotzki 2012; Givens \& Jorgenson 2013; Harring 2013; Hershfield et al. 2014), studies of conservation responses at the national level are sparse. To our knowledge, the only conservation-specific response metrics that have been considered on a national level are biodiversity loss (Shandra et al. 2009; Butchart et al. 2010; Rodrigues et al. 2014), domestic conservation spending (McClanahan \& Rankin 2016), protected area cover (Kashwan 2017) and a composite of these three metrics specifically with regards to megafauna conservation (Lindsey et al. 2017). As previous studies of environmental behaviours show that different metrics respond to different socioeconomic drivers and influences (Hadler \& Haller 2011), we consider multiple metrics of conservation responses. Specifically, we aim to further the understanding of the variation in countrylevel conservation efforts by assessing together additional and previously unconsidered metrics of national-level conservation responses alongside explanatory socioeconomic variables used in previous studies to predict variation between nations in broad environmentalism (Table 1).

\section{METHODS}

We collected socioeconomic and historical data for each of the world's nation states and used these in a multivariate regression analysis to model a number of variables related to national-level conservation responses or performance. Details of the response and explanatory variables selected, their sources and the specific hypotheses they were selected to test are given in Table 2. All analyses were conducted in $\mathbf{R}$ 3.0.1 (R Development Core Team 2014); model selection was implemented using the package 'MuMIn' (Barton 2012). We modelled seven country-level response variables: per capita membership of environmental non-governmental organizations (NGOs); the number of International Union for Conservation of Nature (IUCN) organizations operating in the country; the extent to which Aichi Biodiversity Target 11 to protect biomes has been met; an index of ecosystem vitality; governmental spend on domestic conservation; governmental 
Table 2 Descriptions and sources of the response and explanatory variables used in the analyses. For the explanatory variables, the numbers in parentheses after the variable name link to those given in Table $\mathrm{S} 1$ to indicate which factor previously shown to predict broad environmentalism each was chosen to test. Small or non-independent polities (e.g. San Marino, Gibraltar) and recently created states that are included in the CIA World Factbook (https://www.cia.gov/library/publications/the-world-factbook) but for which many variables were missing (e.g. South Sudan, Somaliland) were removed from the analysis $(n=14)$. GDP $=$ gross domestic product; IUCN $=$ International Union for Conservation of Nature; $\mathrm{NGO}=$ non-governmental organization.

\begin{tabular}{|c|c|}
\hline Variable name & Description and source \\
\hline \multicolumn{2}{|l|}{ Response variables } \\
\hline NGO membership & $\begin{array}{l}\text { Membership of the national partner of BirdLife International. Use of environmental association as a metric } \\
\text { for civic environmentalism follows Dalton (2005) and Longhofer and Schofer (2010), } 2014 \text { values }\end{array}$ \\
\hline IUCN organizations & $\begin{array}{l}\text { Number of IUCN organizations, taken from the IUCN Members' Database } \\
\text { (https://www.iucn.org/about/union/members/who-are-our-members). Use of environmental NGO } \\
\text { presence as a measure of environmental concern follows Smith and Wiest (2005) and Givens and } \\
\text { Jorgenson (2013), } 2014 \text { values }\end{array}$ \\
\hline $\begin{array}{l}\% \text { Aichi Target } 11 \\
\text { achieved }\end{array}$ & $\begin{array}{l}\text { Extent }(\%) \text { to which each country has met Aichi Biodiversity Target } 11 \text { of the Convention on Biological } \\
\text { Diversity for protecting } 17 \% \text { of each biome at a national level (CBD 2010). One of the indices comprises } \\
\text { the wider Ecosystem Vitality Index, which in turn combines with a number of metrics on human health } \\
\text { and well-being to comprise the Environmental Performance Index } 2014 \text { (http://epi.yale.edu/data). We } \\
\text { consider this a more comprehensive metric of biodiversity protection than simply percentage of protected } \\
\text { area cover (e.g. Kashwan 2017) }\end{array}$ \\
\hline Ecosystem vitality & $\begin{array}{l}\text { A composite of the previous index with further indices on ecosystem protection and on water, agriculture, } \\
\text { forests, fisheries, climate and energy. This represents an index of broader ecosystem and } \\
\text { biodiversity-influencing issues than the previous index (http://epi.yale.edu/data), } 2014 \text { values }\end{array}$ \\
\hline $\begin{array}{l}\text { Domestic conservation } \\
\text { spending }\end{array}$ & $\begin{array}{l}\text { Domestic conservation spending in millions of US dollars, taken from Waldron et al. (2013), following } \\
\text { Vincent et al. (2014) and McClanahan and Rankin (2016) }\end{array}$ \\
\hline Multilateral agreements & $\begin{array}{l}\text { The number of multilateral environmental agreements signed, from a set of } 25 \text {. Examples include the } \\
\text { International Convention for the Regulation of Whaling and the Convention on International Trade in } \\
\text { Endangered Species (CITES). Data are taken from the environmental sustainability-adjusted Global } \\
\text { Competitiveness Index (2013-2014 edition). The use of multilateral agreements as a national-level } \\
\text { environmental response follows Neumayer (2002a) }\end{array}$ \\
\hline $\begin{array}{r}\text { Environmental } \\
\text { enforcement }\end{array}$ & $\begin{array}{l}\text { Enforcement of environmental regulations. This score is a component in the environmental } \\
\text { sustainability-adjusted GCI ( } 2013-2014 \text { edition). It is obtained from the World Economic Forum, } \\
\text { Executive Opinion Survey, } 2011 \text { and } 2012 \text { editions. Scores are within-country averages of assessments of } \\
\text { enforcement from } 1=\text { very lax to } 7=\text { among the world's most rigorous. Following Dasgupta } \text { et al. (2001) } \\
\text { and Rivera and Oh (2013) }\end{array}$ \\
\hline \multicolumn{2}{|l|}{ Explanatory variables } \\
\hline GDP (1) & GDP in US dollars, 2013 estimates (World Bank). Linear and quadratic terms included \\
\hline Per-capita GDP (1) & $\begin{array}{l}\text { Per-capita GDP in US dollars corrected for purchasing power parity, } 2013 \text { estimates (World Bank; } \\
\text { http://data.worldbank.org/indicator/NY.GDP.PCAP.PP.CD). For the small number of countries } \\
\text { without estimates, the uncorrected per-capita GDP was entered to maintain sample sizes. Linear and } \\
\text { quadratic terms were included }\end{array}$ \\
\hline Country age (5) & Age of country as given in the CIA World Factbook as of 2014 \\
\hline Globalization $(4,6)$ & $\begin{array}{l}\text { Swiss Economic Institute Index of Globalization (Dreher 2006), } 2012 \text { values. This index measures a } \\
\text { country's level of economic, social and political globalization and includes data on economic flows and } \\
\text { restrictions, information flow and cultural proximity }\end{array}$ \\
\hline Governance $(2,5,6)$ & $\begin{array}{l}\text { Worldwide governance indicators (World Bank). These indicators score countries on six measures of } \\
\text { governance: voice and accountability; political stability and absence of violence; government } \\
\text { effectiveness; regulatory quality; rule of law; and control of corruption. Each measure is scaled in the } \\
\text { same way; we used the } 2012 \text { average across all six measures } \\
\text { (http://data.worldbank.org/data-catalog/worldwide-governance-indicators) }\end{array}$ \\
\hline Development $(1,4)$ & $\begin{array}{l}\text { Human Development Index (United Nations Development Programme). A composite statistic of life } \\
\text { expectancy, education and income indices, } 2013 \text { values }\end{array}$ \\
\hline Post-materialism (3) & $\begin{array}{l}\text { Most recent value for each country from either the World Values Survey Wave } 6(2010-2014) \text { or the World } \\
\text { Values Survey Wave } 5(2005-2009) \text {. Because of the small sample size, this variable was tested in a } \\
\text { separate set of analyses (Table S4) }\end{array}$ \\
\hline
\end{tabular}


adoption of multilateral environmental agreements; and the enforcement of environmental regulations. These variables were selected because they include independent metrics that relate to a range of public and national responses to the biodiversity crisis, which have previously not been considered together in similar analyses. Additionally, data were available for each variable for a sufficiently large number of countries (over 90) to allow multivariate modelling. The seven response variables were not strongly inter-correlated (Table S1, available online). Based on previous studies of variation between nations in broad environmentalism and the hypotheses already reviewed (Table 1), we initially considered seven explanatory variables: gross domestic product (GDP); per-capita GDP (adjusted for purchasing power parity); country age; level of globalization; quality of governance; level of human development; and degree of post-materialism (Table 2). The Human Development Index was highly correlated with both per-capita GDP and globalization $(r>0.8$; Table S2) and therefore excluded, as data were available for fewer countries. The small sample size $(n=76$ countries) of the only available multinational metric of postmaterialism meant that including this variable in analyses would reduce statistical power. Thus, we assessed two sets of models: one fitting the five explanatory variables with large sample sizes (GDP, per-capita GDP, country age, globalization and governance) and the other with these five variables plus post-materialism. We included linear and quadratic terms of GDP and per-capita GDP to assess evidence of EKCs (Grossman \& Krueger 1995). We also tested interaction terms between: (i) GDP and governance; and (ii) per-capita GDP and governance.

We used generalized linear models (GLMs) to model each response variable as a function of the two sets of explanatory variables. We standardized all explanatory variables to compare the effect size among explanatory variables and normalized GDP, per-capita GDP and country age using $\log _{10}$ transformation. Because NGO membership and the number of IUCN organizations are likely to vary with population size and because we could not model the per-capita values of these because per-capita GDP was included as a predictor (thus meaning that population size would appear on both sides of the regression equation, causing spurious correlations), the population size of each nation was also included as a predictor in these models to control for its effect, though we do not report its result. Statistical distributions assumed in the GLMs were based on the type of the response variables: normal for $\log _{10}$-transformed NGO membership, ecosystem vitality and environmental enforcement; negative binomial for the IUCN organizations; binomial for Aichi Target 11 progress and multilateral agreements; and Gamma for square root-transformed domestic conservation spending. We adopted a model selection approach (Burnham \& Anderson 2002). We generated a set of models with all possible parameter subsets, which were then fitted to the data using the GLMs and ranked by $\triangle$ QAICc (the difference between each model's corrected quasi-likelihood Akaike information criterion (QAICc) and $\mathrm{QAICc}_{\text {min }}$, that of the 'best' model) for binomial GLMs to deal with over-dispersion and $\triangle \mathrm{AICc}$ for others. We report the top ten models or all models with $\triangle \mathrm{AICc}$ or $\triangle \mathrm{QAICc}$ values $<2$ for each analysis. To investigate the effect of spatial autocorrelation, we calculated Moran's $I$ for the residuals from the full models using the package 'ncf' (Bjørnstad 2005) in R. The calculated Moran's $I$ was small ( $\mid$ Moran's $I \mid<0.3$ ) up to the first $14000 \mathrm{~km}$ in all the databases, indicating no more than a weak autocorrelation. Thus, we did not consider spatial autocorrelation explicitly in the models.

Considering the relatively strong positive correlations between governance, per-capita GDP and globalization $(r=$ 0.71-0.77; Table S2), we also adopted a variation partitioning approach (Borcard et al. 1992) to assess the unique and shared contributions of these three explanatory variables to explaining between-nation variation in conservation responses. We used $R^{2}$ for GLMs assuming normal distribution (NGO membership, ecosystem vitality and environmental enforcement) and McFadden's pseudo- $R^{2}$ for others. We excluded the quadratic and interaction terms of per-capita GDP.

\section{RESULTS}

Model selection yielded strong support for an effect of governance in explaining variation in almost all the response variables modelled. Governance was the only explanatory variable that was included in all models of all response variables with $\triangle \mathrm{AICc}$ or $\triangle \mathrm{QAICc}$ values $<2$ (Table $\mathrm{S} 3$ ). The response variables all showed a strong positive association with governance (Fig. 1(a)). The results also identified GDP as a significant predictor, as it was included in more than half the models with $\triangle$ AICc or $\triangle$ QAICc values $<2$, including the best models of six response variables (Fig. 1(b), Table S3).

The same key role of governance was found in the models that included a measure of post-materialism, except in the case of the number of IUCN organizations (Table S4). Postmaterialism itself failed to explain significant variation in any of the response variables (Table S4). We did not find clear evidence of an EKC for any of our conservation response variables besides ecosystem vitality, for which there was a weak indication of an EKC.

The variation partitioning showed that the unique contribution of governance was higher than that of per-capita GDP and globalization in accounting for variation in four of the seven response variables. However, for all but one response variable the variation was best explained by the three variables (governance, per-capita GDP and globalization) combined, rather than any one of them alone (Fig. 2).

\section{DISCUSSION}

Our analyses yielded equivocal support for the largely economic hypotheses that have been developed to explain variation in broad environmentalism. GDP received support 

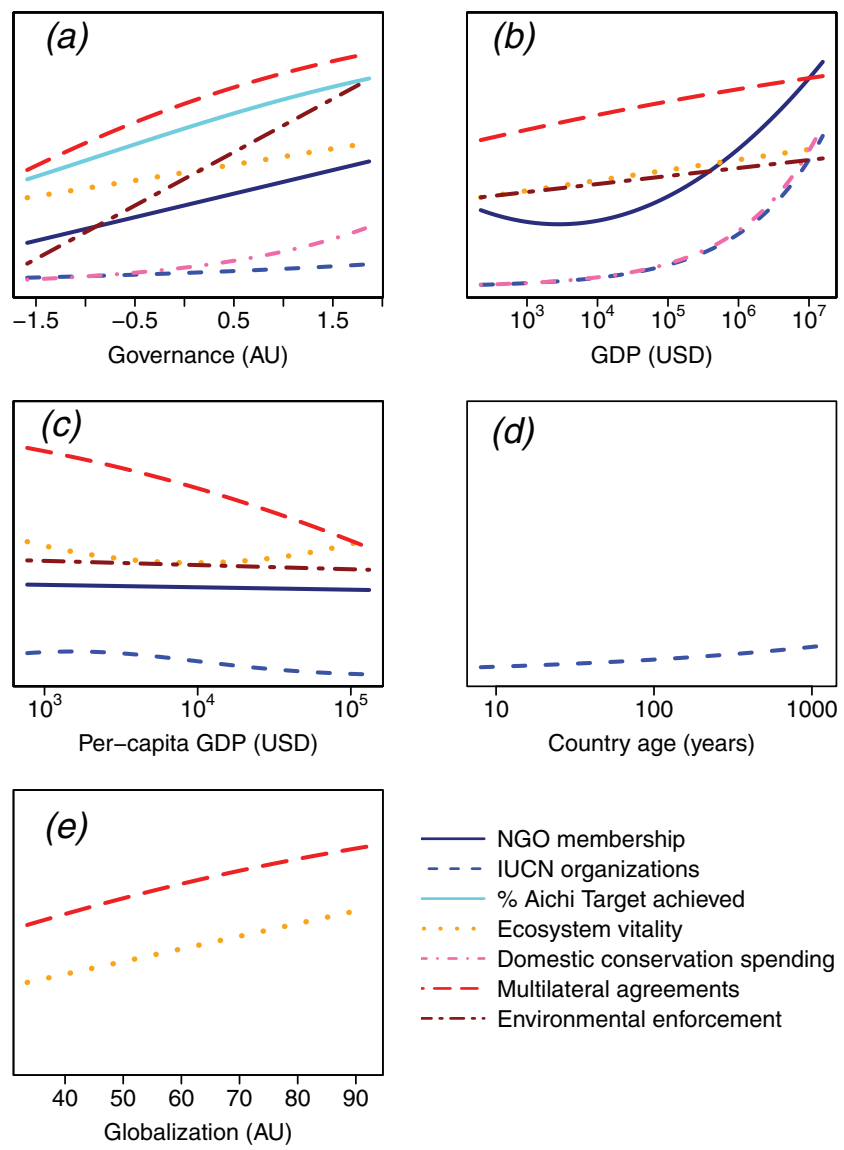

Figure 1 Relationships between seven response variables reflecting conservation concerns and $(a)$ governance, $(b)$ GDP, $(c)$ per-capita GDP, $(d)$ country age and $(e)$ globalization. Lines represent regression lines based on the estimated coefficients in the best models (Table S3). Lines are not shown for variables not included in the best models. The $y$-axes differ between response variables. GDP = gross domestic product; IUCN = International Union for Conservation of Nature; $\mathrm{NGO}=$ non-governmental organization; $\mathrm{USD}=\mathrm{US}$ dollars.

in models of only some response variables, including for conservation spending, mirroring the results of McClanahan and Rankin (2016). Post-materialism failed to explain variation in any of the variables modelled. Globalization also failed to garner much support from the data as being a useful predictor. Country age was the best predictor of the number of IUCN organizations within a country, which lends support to the observation by Herschfield et al. (2014) that country age is a predictor of public environmental concern. However, country age was a poor predictor of other conservation metrics and effective environmental organization may not necessarily reflect underlying public environmental concern (Longhofer \& Schofer 2010). Instead, governance was found to be the best predictor across almost all variables, suggesting that world polity theory and Pinker's (2011) 'civilising process' might be useful frameworks with which to explore further (a) NGO membership

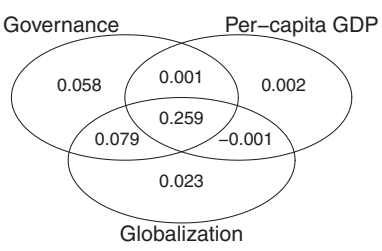

(c) \% Aichi Target achieved

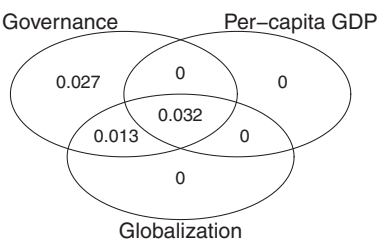

(e) Domestic conservation spending

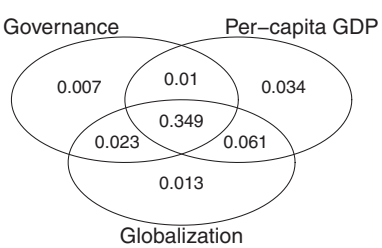

(g) Environmental enforcements

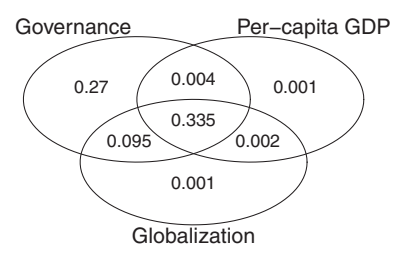

Figure 2 Results of variation partitioning for $(a)$ NGO membership, (b) IUCN organizations, (c) \% Aichi Target achieved, (d) ecosystem vitality, (e) domestic conservation spending, $(f)$ multilateral agreements and $(g)$ environmental enforcements, in terms of fractions of variation explained independently and jointly by governance, per-capita GDP and globalization. GDP = gross domestic product; IUCN = International Union for Conservation of Nature; $\mathrm{NGO}=$ non-governmental organization.

the between-nation variation in conservation responses and performance. The extent to which governance was a better predictor of responses to biodiversity conservation than economic wealth was unexpected and cannot be explained by covariance between governance, per-capita GDP and globalization, since variation partitioning revealed that, in four out of the seven response variables, the independent contribution of governance to explaining variation in response variables was far greater than that of the other two variables. Governance has been shown to be an important predictor of biodiversity loss (Smith et al. 2003), deforestation rates (Wright et al. 2007; Umemiya et al. 2010), protected area effectiveness (Barnes et al. 2016) and poaching (Burn et al. 2011), but as far as we are aware, ours is the first analysis to suggest that governance outperforms more purely economic variables in explaining a range of metrics of 
conservation effort and investment across most of the world's nations.

Although the causal links between governance and biodiversity conservation remain unclear, there are several plausible mechanisms. The relationship between biodiversity and corruption is complex and poorly understood (Smith \& Walpole 2005; Barrett et al. 2006), but willingness to make economic sacrifices for environmental protection appears to be strongly affected by individual political trust (Harring 2013). The over-centralization typical of countries with lower governance scores may inhibit local conservation actions (Everard 2015; Zheng \& Cao 2015) and in these states conservation policy may not be supported by the development of legal standards and procedures (Otto et al. 2011). Effective governance might promote the growth of agricultural yields while minimizing the spread of uncontrolled, particularly damaging agriculture (Ceddia et al. 2014). Internal strife and conflict, the rates of which are explicitly captured in governance statistics, have generally negative impacts on biodiversity (Dudley et al. 2002). On a local scale, better governance may increase the strength of local institutions and improve common-pool resource management, particularly where property rights are lacking (Ostrom et al. 2007). Likewise, less effective governance undermines sustainable harvest (Nelson et al. 2013; Schuhbauer \& Sumaila 2016) and incentive-based conservation (Ebeling \& Yasué 2009; Duchelle et al. 2014). Finally, improved quality of governance may be associated with greater engagement with international conservation agreements. For example, European countries must achieve an acceptable level of governance before they can accede to the European Union, upon which they are bound to strict conservation legislation that has been shown to be successful (Donald et al. 2007), although such legislation is not always enforced (López-Bao et al. 2015). Democracies perform better than other systems of government in joining and implementing international conservation agreements and in protecting land for wildlife (Neumayer 2002a).

Our finding that globalization correlates with some conservation responses (multilateral agreements and ecosystem vitality) corroborates Neumayer (2002b), who found a positive association between trade openness and the ratification of multilateral environmental agreements. However, the absence of a relationship between globalization and our other response variables suggests that economic, social and political connectivity by themselves do not increase conservation efforts. Instead, if conservation responses have spread around the globe, it might be down to the influence of specific actors, such as international environmental organizations (Shandra et al. 2009; Givens \& Jorgenson 2013). Given the significance of governance identified here, the influence of world polity on conservation may also have occurred indirectly via the building of conservation capacity through democratic institutions and governance systems (Dunlap \& York 2008). This link is supported by the finding that international NGOs help reduce deforestation and do so increasingly at higher levels of democracy (Shandra 2007).
Conservation responses may also be influenced by other forms of capacity, however. Environmental organizations, for example, appears to depend heavily on the availability of financial resources, the concentration of individuals in populated urban areas (Gillham 2008) and levels of education and awareness (Brady et al. 1995; Duroy 2008). These factors, which we did not specifically test here, might also account for why the number of IUCN organizations did not correlate with governance as strongly as our other response variables. Furthermore, all these factors identified that occur at the national level may overshadow the influence of postmaterialist values at the individual level (Kemmelmeier et al. 2002), thus perhaps explaining why we fail to find an effect of post-materialism here. Alternatively, this might be because conservation problems have both materialist and non-materialist dimensions in both rich and poor nations (Martinez-Alier \& Guha 1997; Dunlap \& York 2008). Indeed, the range of conservation motivations is reflected in the many types of (materialist and non-materialist) ecosystem services identified across all societies (Crossman et al. 2013; Raymond \& Kenter 2016). Moreover, given that postmaterialist values and resulting environmental behaviours are supposed to be the products of prosperity (Inglehart 1995; 2000), the lack of a clear relationship between our conservation responses and per-capita wealth refutes the post-materialism hypothesis.

We also found no evidence for an EKC for conservation responses. Ecosystem vitality was the only variable that showed a relationship resembling a weak EKC, but this effect may be down to the indices of water pollution and air quality, which make up the majority of the ecosystem vitality index (Morse 2017) and have previously been found to follow the EKC, rather than biodiversity. Along with economic growth driving increasing environmental concern and demand, a key tenant of the EKC, is that technological progress eventually reduces environmental degradation. However, technological progress has not yet produced similar results for conservation, owing to slow speciation rates (Dietz \& Adger 2003), competitive exclusion of non-human species and challenges involved in habitat restoration (Czech 2008), which might explain the lack of an EKC for biodiversity metrics. Indeed, wealth appears only to start reducing biodiversity loss once a minimal level of institutional quality has been achieved (Gren et al. 2016), again emphasizing the significance of governance in determining conservation outcomes. However, our other responses, which relate more to conservation concern and effort, also showed no EKC relationship. This finding suggests that conservation efforts will not readily decline as poorer nations develop and that greater wealth does not necessarily inspire greater conservation efforts, despite the notion that richer people may be more willing to pay for conservation (Jacobsen \& Hanley 2009; Franzen \& Meyer 2010). Lastly, again departing from an EKC, some poorer nations may prioritize conservation for economic reasons (such as ecotourism) and, unlike other forms of environmental degradation, the direct links between biodiversity loss and 


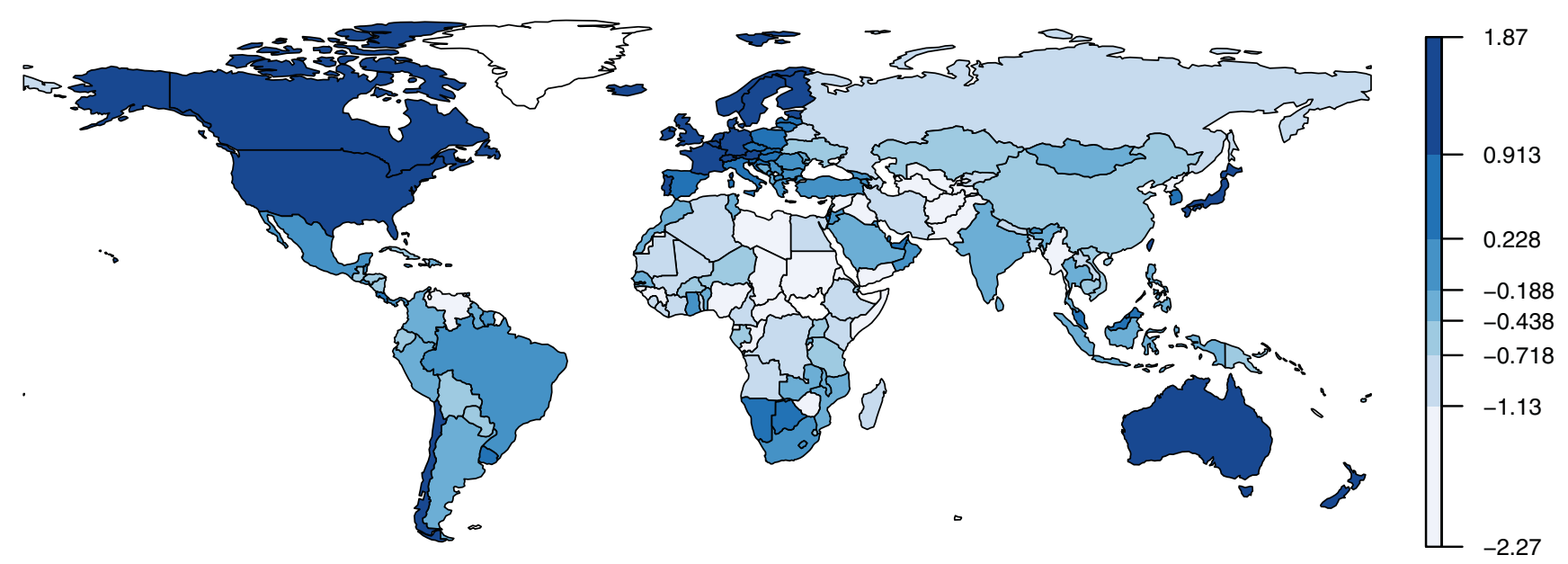

Figure 3 The global distribution of the World Bank's worldwide governance indicators (2013 values).

human well-being (Díaz et al. 2006) may be appreciated differently by citizens and policy makers across the world.

We did not identify inequality as being one of the key hypothesized drivers of environmentalism (hence we did not account for it in our analysis), but inequality may also influence conservation responses. Environmental performance of nations appears to increase with equality (Morse 2017), but protected area cover also depends on the strength of democracy (Kashwan 2017). In countries with strong democracies, low inequality is associated with higher protected area cover, but in weak democracies, higher inequality is associated with greater protected area cover (Kashwan 2017), possibly because establishing conservation areas may be easier in areas of weaker property rights, greater power associated with elites (including environmental organizations) (Sandbrook 2017) and limited civic ability to contest (Kashwan 2017). This result challenges our findings by demonstrating that some conservation responses can proliferate under less effective governance. However, protected area cover is also associated with remoteness (Joppa \& Pfaff 2009) and tourism attractiveness (Baldi et al. 2017), suggesting a degree of strategic planning or opportunism that deserves greater exploration. Besides, the size of protected area coverage is not necessarily indicative of its quality (De Santo 2013); instead, local governance seems to be a key driver of conservation and social outcomes (Oldekop et al. 2016).

Wealthier countries tend on average to have higher levels of governance, but there is a sufficient number of wealthy countries with less effective governance and poor countries with effective governance to justify treating governance as an informative metric in its own right and not simply a surrogate of wealth. Given the importance of governance in explaining countries' conservation responses and investment, this provides important insights into future changes in global conservation activities. Many countries in biodiversity-rich regions, such as South Asia, sub-Saharan Africa and Latin America and the Caribbean, now have rapidly growing economies, posing serious threats to biodiversity in these regions (Bradshaw et al. 2010). However, governance in these regions is generally low (Fig. 3), suggesting that their levels of positive conservation responses and investment are unlikely to increase in the near future. This suggests a further challenge to achieving the Aichi Biodiversity Targets, which aim to improve the status of biodiversity and enhance the implementation of effective biodiversity strategies and action plans by 2020 (CBD 2010).

Nonetheless, governance is dynamic and can change within countries over time (Inglehart \& Welzel 2005). Whilst the potential for improved governance is encouraging for conservation, periods of instability and armed conflict can easily threaten biodiversity (Loucks et al. 2009; Brashares et al. 2014) and even in wealthy, well-governed states environmental regulations can readily be disregarded, diminished and discarded (López-Bao et al. 2015; Chapron et al. 2017). Wealthy, well-governed states may also appear to superficially improve their conservation performance by transferring the ecological footprint of their consumption and industry to poorer, less well-governed nations in 'unequal ecological exchange' (Jorgenson 2016). Scrutinizing such patterns further and improving the transparency of transnational supply chains would help tackle this problem. The nature of conservation governance is also subject to change (Agrawal et al. 2008; Duffy 2014) with sometimes unintended negative consequences, such as perverse incentives (Gordon et al. 2015) or stakeholder resentment (Bennet \& Dearden 2014). Existing local governance structures can also outperform centralized state regimes (such as protected areas) in some places (Schleicher et al. 2017). These effects should be appreciated 
when considering new forms of environmental governance, including digital crypto-governance, which has been tipped to improve environmental record keeping and reduce corruption with blockchain technology (Chapron 2017). The digital world is also increasingly offering new ways for individuals to engage with conservation online, presenting opportunities for increased participation (Baynham-Herd 2017), but also new challenges, including for conservation governance (Büscher 2017).

We suggest that metrics relating to governance might also be of considerable use in conservation planning. Like economic costs (Naidoo et al. 2006), governance scores could be used for assessing where conservation investments and capacity building would most profitably be directed and for determining the types of conservation action (capacity development or practical delivery) that are most likely to bear fruit (Eklund et al. 2011; Garnett et al. 2011). Indeed, there is evidence that international aid for biodiversity conservation is already being targeted at recipient countries that have higher levels of governance (Miller et al. 2013). Wider recognition of the link between governance and conservation may encourage greater collaboration between conservation interests and those working to promote better governance. Environmental NGOs have already contributed to this process and have helped construct a world polity that speeds up the transfer of conservation as a universal principle between nations (Boli \& Thomas 1997; Longhofer \& Schofer 2010; Givens \& Jorgenson 2013). At the local level, working to improve conservation governance might also prove more productive than trying to generate shifts in conservation values (Manfredo et al. 2017). Lastly, we suggest our findings should promote further scrutiny regarding the notion that through economic growth alone we will escape from this biodiversity crisis. There is more to conservation than markets: governance must be considered alongside growth.

\section{ACKNOWLEDGEMENTS}

We are very grateful for the constructive comments that we received from Guillaume Chapron, an anonymous second reviewer and the Associate Editor, Aaron MacNiel.

\section{FINANCIAL SUPPORT}

No funding was required for this research. WJS is funded by Arcadia. ZBH is funded by the Natural Environment Research Council (NERC).

\section{CONFLICT OF INTEREST}

None.

\section{ETHICAL STANDARDS}

This study did not involve any human or animal subjects and all data analysed were freely available online.

\section{Supplementary Material}

To view supplementary material for this article, please visit https://doi.org/10.1017/S037689291700056X

\section{References}

Abramson, P.R. (1997) Postmaterialism and environmentalism: A comment on an analysis and a reappraisal. Social Science Quarterly 78: 21-23.

Adams, W.M., Aveling, R., Brockington, D., Dickson, B., Elliott, J., Hutton, J., Roe, D., Vira, B. \& Wolmer, W. (2004) Biodiversity conservation and the eradication of poverty. Science 306: 11461149.

Agrawal, A., Chhatre, A. \& Hardin, R. (2008) Changing governance of the world's forests. Science 320: 1460-1462.

Apergis, N. \& Ozturk, I. (2015) Testing environmental Kuznets curve hypothesis in Asian countries. Ecological Indicators 52: 1622.

Baldi, G., Texeira, M., Martin, O.A., Grau, H.R. \& Jobbágy, E.G. (2017) Opportunities drive the global distribution of protected areas. Peer7 5: e2989.

Barnes, M.D., Craigie, I.D., Harrison, L.B. et al. (2016) Wildlife population trends in protected areas predicted by national socioeconomic metric and body size. Nature Communications 7: 12747.

Barrett, C.B., Gibson, C.C., Hoffman, B. \& McCubbins, M.D. (2006) The complex links between governance and biodiversity. Conservation Biology 20: 1358-1366.

Bartoń, K. (2012) MuMIn: Multi-model inference: R package [www document]. URL http://cran.r-project.org/web/ packages/MuMIn/index.html

Baynham-Herd, Z. (2017) Technology: Enlist blockchain to boost conservation. Nature 548: 523.

Bennett, N.J. \& Dearden, P. (2014) Why local people do not support conservation: Community perceptions of marine protected area livelihood impacts, governance and management in Thailand. Marine Policy 44: 107-116.

Bjørnstad, O.N. (2005) ncf: spatial nonparametric covariance functions. R package [www document]. URL http://cran.r-project. org/web/packages/ncf/index.html

Boli, J. \& Thomas, GM. (1997) World culture in the world polity: A century of international non-governmental organization. American Sociological Reviem 62: 171-190.

Borcard, D., Legendre, P. \& Drapeau, P. (1992) Partialling out the spatial component of ecological variation. Ecology 73: 1045-1055.

Bradshaw, C.J.A., Giam, X. \& Sodhi, NS. (2010) Evaluating the relative environmental impact of countries. PLoS ONE 5: e10440.

Brady, H.E., Verba, S. \& Schlozman, K.L. (1995) Beyond SES: A resource model of political participation. American Political Science Reviem 89: 271-294.

Brashares, J.S., Abrahms, B., Fiorella, K.J., Golden, C.D., Hojnowski, C.E., Marsh, R.A., McCauley, D.J., Nuñez, T.A., Seto, K. \& Withey, L. (2014) Wildlife decline and social conflict. Science 345: 376-378.

Burn, R.W., Underwood, F.M. \& Blanc, J. (2011) Global trends and factors associated with the illegal killing of elephants: A hierarchical Bayesian analysis of carcass encounter data. PLoS ONE 6: e24165. 
Büscher, B. (2017) Conservation and development 2.0: Intensifications and disjunctures in the politics of online 'do-good' platforms. Geoforum 79: 163-173.

Burnham, K.P. \& Anderson, D.R. (2002) Model Selection and Multimodel Inference: A Practical Information-Theoretic Approach, 2nd ed. New York, NY, USA: Springer-Verlag.

Butchart, S.H.M., Walpole, M, Collen, B. et al. (2010) Global biodiversity: Indicators of recent declines. Science 328: 1164-1168.

CBD (2010) Decision X/2. The Strategic Plan for Biodiversity 2011-2020 and the Aichi Biodiversity Targets. Montreal, Canada: Secretariat of the Convention on Biological Diversity.

Ceddia, M.G., Bardsley, N.O., Gomez-y-Paloma, S. \& Sedlacek, S. (2014) Governance, agricultural intensification, and land sparing in tropical South America. Proceedings of the National Academy of Sciences of the United States of America 111: 7242-7247.

Chapron, G. (2017) The environment needs cryptogovernance. Nature 545: 403.

Chapron, G., Epstein, Y., Trouwborst, A. \& López-Bao, J.V. (2017) Bolster legal boundaries to stay within planetary boundaries. Nature Ecology E Evolution 1: 86.

Clements, B. (2012) The sociological and attitudinal bases of environmentally-related beliefs and behaviour in Britain. Environmental Politics 21: 901-921.

Crossman, N.D., Burkhard, B., Nedkov, S., Willemen, L., Petz, K., Palomo, I., Drakou, E.G., Martín-Lopez, B., McPhearson, T., Boyanova, K. \& Alkemade, R. (2013) A blueprint for mapping and modelling ecosystem services. Ecosystem Services 4: 4-14.

Czech, B. (2008) Prospects for reconciling the conflict between economic growth and biodiversity conservation with technological progress. Conservation Biology 22: 1389-1398.

Dalton, R.J. (2005) The greening of the globe? Cross-national levels of environmental group membership. Environmental Politics 14: 441-459.

Dasgupta, S., Mody, A., Roy, S. \& Wheeler, D. (2001) Environmental regulation and development: A cross-country empirical analysis. Oxford Development Studies 29: 173-187.

Davis, D.W. (2000) Individual level examination of postmaterialism in the US: Political tolerance, racial attitudes, environmentalism, and participatory norms. Political Research Quarterly 53: 455475.

De Santo, E.M. (2013) Missing marine protected area (MPA) targets: How the push for quantity over quality undermines sustainability and social justice. Fournal of Environmental Management 124: 137146.

Díaz, S., Fargione, J., Chapin III, F.S. \& Tilman, D. (2006) Biodiversity loss threatens human well-being. PLoS Biology 4: e277.

Diekmann, A. \& Franzen, A. (1999) The wealth of nations and environmental concern. Environment and Behavior 31: 540-549.

Dietz, S. \& Adger, W.N. (2003) Economic growth, biodiversity loss and conservation effort. Fournal of Environmental Management 68: 23-35.

Dietz, T., Fitzgerald, A. \& Shwom, R. (2005) Environmental values. Annual Reviem Environmental Resources 30: 335-372.

Dietz, T., Rosa, E.A. \& York, R. (2007) Driving the human ecological footprint. Frontiers in Ecology and the Environment 5: 13-18.

Dinda, S. (2004) Environmental Kuznets curve hypothesis: A survey. Ecological Economics 49: 431-455.

Dobewall, H. \& Strack, M. (2014) Relationship of Inglehart's and Schwartz's value dimensions revisited. International fournal of Psychology 49: 240-248.
Donald, P.F., Sanderson, F.J., Burfield, I.J., Bierman, S.M., Gregory, R.D. \& Waliczky, Z. (2007) International conservation policy delivers benefits for birds in Europe. Science 317: 810 813.

Dreher, A. (2006) Does globalization affect growth? Evidence from a new index of globalization. Applied Economics 38: 1091-1110.

Duchelle, A.E., Cromberg, M., Gebara, M.F., Guerra, R., Melo, T., Larson, A., Cronkleton, P., Börner, J., Sills, E., Wunder, S. \& Bauch, S. (2014) Linking forest tenure reform, environmental compliance, and incentives: Lessons from REDD+ initiatives in the Brazilian Amazon. World Development 55: 53-67.

Dudley, J.P., Ginsberg, J.R., Plumptre, A.J., Hart, J.A. \& Campos, L.C. (2002) Effects of war and civil strife on wildlife and wildlife habitats. Conservation Biology 16: 319-329.

Duffy, R. (2014) Waging a war to save biodiversity: The rise of militarized conservation. International Affairs 90: 819-834.

Dunlap, R.E. \& Mertig, A.G. (1997) Global environmental concern: An anomaly for postmaterialism. Social Science Quarterly 78: 24 29.

Dunlap, R.E. \& York, R. (2008) The globalization of environmental concern and the limits of the postmaterialist values explanation: Evidence from four multinational surveys. Sociological Quarterly 49: 529-563.

Duroy, Q.M. (2008) Testing the affluence hypothesis: A crosscultural analysis of the determinants of environmental action. The Social Science fournal 45: 419-439.

Ebeling, J. \& Yasué, M. (2009) The effectiveness of market-based conservation in the tropics: Forest certification in Ecuador and Bolivia. Fournal of Environmental Management 90: 1145-1153.

Eklund, J., Arponen, A., Visconti, P. \& Cabeza, M. (2011) Governance factors in the identification of global conservation priorities for mammals. Philosophical Transactions of the Royal Society B - Biological Sciences 366: 2661-2669.

Everard, M. (2015) Community-based groundwater and ecosystem restoration in semi-arid north Rajasthan (1): Socio-economic progress and lessons for groundwater-dependent areas. Ecosystem Services 16: 125-135.

Everard, M., Reed, M.S. \& Kenter, J.O. (2016) The ripple effect: Institutionalising pro-environmental values to shift societal norms and behaviours. Ecosystem Services 21: 230-240.

Fairbrother, M. (2013) Rich people, poor people, and environmental concern: Evidence across nations and time. European Sociological Reviem 29: 910-922.

Frank, D.J. (1999) The social bases of environmental treaty ratification, 1900-1990. Sociological Inquiry 69: 523-550.

Frank, D.J., Hironaka, A. \& Schofer, E. (2000) The nation-state and the natural environment over the twentieth century. American Sociological Reviem 65: 96-116.

Franzen, A. (2003) Environmental attitudes in international comparison: An analysis of the ISSP surveys 1993 and 2000. Social Science Quarterly 84: 297-308.

Franzen, A. \& Meyer, R. (2010) Environmental attitudes in crossnational perspective: A multilevel analysis of the ISSP 1993 and 2000. European Sociological Reviem 26: 219-234.

Franzen, A. \& Vogl, D. (2013) Two decades of measuring environmental attitudes: A comparative analysis of 33 countries. Global Environmental Change - Human and Policy Dimensions 23: 1001-1008.

Garnett, S.T., Joseph, L.N., Watson, J.E.M. \& Zander, K.K. (2011) Investing in threatened species conservation: Does corruption outweigh purchasing power? PLoS ONE 6: e22749. 
Gelissen, J. (2007) Explaining popular support for environmental protection - A multilevel analysis of 50 nations. Environment and Behavior 39: 392-415.

Gifford, R. \& Nilsson, A. (2014) Personal and social factors that influence pro-environmental concern and behaviour: A review. International fournal of Psychology 49: 141-157.

Gillham, P.F. (2008) Participation in the environmental movement: Analysis of the European Union. International Sociology 23: 6793.

Gordon, A., Bull, J.W., Wilcox, C. \& Maron, M. (2015) Perverse incentives risk undermining biodiversity offset policies. Fournal of Applied Ecology 52: 532-537.

Givens, J.E. \& Jorgenson, A.K. (2011) The effects of affluence, economic development, and environmental degradation on environmental concern: A multilevel analysis. Organization $\mathbb{E}$ Environment 24: 74-91.

Givens, J.E. \& Jorgenson, A.K. (2013) Individual environmental concern in the world polity: A multilevel analysis. Social Science Research 42: 418-431.

Gren, M., Campos, M. \& Gustafsson, L. (2016) Economic development, institutions, and biodiversity loss at the global scale. Regional Environmental Change 16: 445-457.

Grossman, G.M. \& Krueger, A.B. (1995) Economic growth and the environment. Quarterly Fournal of Economics 110: 353-377.

Grove, R.H. (1996) Green Imperialism: Colonial Expansion, Tropical Island Edens and the Origins of Environmentalism, 1600-1860. Cambridge, UK: Cambridge University Press.

Hadler, M. \& Haller, M. (2011) Global activism and nationally driven recycling: The influence of world society and national contexts on public and private environmental behavior. International Sociology 26: $315-345$.

Hand, C.M. \& Van Liere, K.D. (1984) Religion, mastery-overnature, and environmental concern. Social Forces 63: 555570

Harring, N. (2013) Understanding the effects of corruption and political trust on willingness to make economic sacrifices for environmental protection in a cross-national perspective. Social Science Quarterly 94: 660-671.

Harring, N., Jagers, S.C. \& Martinsson, J. (2011) Explaining ups and downs in the public's environmental concern in Sweden: The effects of ecological modernization, the economy, and the media. Organization E Environment 24: 388-403.

Heath, Y. \& Gifford, R. (2006) Free-market ideology and environmental degradation. The case of belief in global climate change. Environment and Behavior 38: 48-71.

Heberlein, T.A. (2012) Navigating Environmental Attitudes. Oxford, UK: Oxford University Press.

Hershfield, H.E., Bang, H.M. \& Weber, E.U. (2014) National differences in environmental concern and performance are predicted by country age. Psychological Science 25: 152-160.

Ignatow, G. (2006) Cultural models of nature and society reconsidering environmental attitudes and concern. Environment and Behavior 38: 441-461.

Inglehart, R. (1995) Public support for environmental protection Objective problems and subjective values in 43 societies. Political Science E Politics 28: 57-72.

Inglehart, R. (2000) Globalization and postmodern values. Washington Quarterly 23: 215-228.

Inglehart, R. \& Welzel, C. (2005) Modernization, Cultural Change, and Democracy: The Human Development Sequence. Cambridge, UK: Cambridge University Press.
Jacobsen, J.B. \& Hanley, N. (2009) Are there income effects on global willingness to pay for biodiversity conservation? Environmental and Resource Economics 43: 137-160.

Johansson, M., Rahm, J. \& Gyllin, M. (2013) Landowners' participation in biodiversity conservation examined through the value-belief-norm theory. Landscape Research 38: 295-311.

Joppa, L.N. \& Pfaff, A. (2009) High and far: Biases in the location of protected areas. PLoS ONE 4: e8273.

Jorgenson, A.K. (2016) Environment, development, and ecologically unequal exchange. Sustainability 8: 227.

Kahn, M.E. (2002) Demographic change and the demand for environmental regulation. Fournal of Policy Analysis and Management 21: 45-62.

Kansky, R. \& Knight, A.T. (2014) Key factors driving attitudes towards large mammals in conflict with humans. Biological Conservation 179: 93-105.

Kashwan, P. (2017) Inequality, democracy, and the environment: A cross-national analysis. Ecological Economics 131: 139-151.

Kemmelmeier, M., Krol, G. \& Kim, Y.H. (2002) Values, economics, and proenvironmental attitudes in 22 societies. Cross-Cultural Research 36: 256-285.

Kidd, Q. \& Lee, A.R. (1997) Postmaterialist values and the environment: A critique and reappraisal. Social Science Quarterly 78: $1-15$.

Kijima, M., Nishide, K. \& Ohyama, A. (2010) Economic models for the environmental Kuznets curve: A survey. Fournal of Economic Dynamics and Control 34: 1187-1201.

Koop, G. \& Tole, L. (1999) Is there an environmental Kuznets curve for deforestation? Fournal of Development economics 58: 231244.

Lindsey, P.A., Chapron, G., Petracca, L.S., Burnham, D., Hayward, M.W., Henschel, P., Hinks, A.E., Garnett, S.T., Macdonald, D.W., Macdonald, E.A. \& Ripple, W.J. (2017) Relative efforts of countries to conserve world's megafauna. Global Ecology and Conservation 10: 243-252.

Longhofer, W. \& Schofer, E. (2010) National and global origins of environmental association. American Sociological Reviem 75: 505533.

López-Bao, J.V., Blanco, J.C., Rodríguez, A., Godinho, R., Sazatornil, V., Alvares, F., García, E.J., Llaneza, L., Rico, M., Cortés, Y. \& Palacios, V. (2015) Toothless wildlife protection laws. Biodiversity and Conservation 24: 2105-2108.

Loucks, C., Mascia, M.B., Maxwell, A., Huy, K., Duong, K., Chea, N., Long, B., Cox, N. \& Seng, T. (2009) Wildlife decline in Cambodia, 1953-2005: Exploring the legacy of armed conflict. Conservation Letters 2: 82-92.

Luzzati, T. \& Orsini, M., (2009) Investigating the energyenvironmental Kuznets curve. Energy 34: 291-300.

Manfredo, M.J., Bruskotter, J.T., Teel, T.L., Fulton, D., Schwartz, S.H., Arlinghaus, R., Oishi, S., Uskul, A.K., Redford, K., Kitayama, S. \& Sullivan, L. (2017) Why social values cannot be changed for the sake of conservation. Conservation Biology 31: 772-780.

Manfredo, M.J., Teel, T.L. \& Dietsch, A.M. (2016) Implications of human value shift and persistence for biodiversity conservation. Conservation Biology 30: 287-296.

Martinez-Alier, J. \& Guha, R. (1997) Varieties of Environmentalism: Essays North and South. London, UK: Earthscan.

McClanahan, T.R. \& Rankin, P.S. (2016) Geography of conservation spending, biodiversity, and culture. Conservation Biology 30: 10891101. 
Meyer, R. \& Liebe, U. (2010) Are the affluent prepared to pay for the planet? Explaining willingness to pay for public and quasi-private environmental goods in Switzerland. Population and Environment 32: 42-65.

Miller, D.C., Agrawal, A. \& Roberts, T. (2013) Biodiversity, governance, and the allocation of international aid for conservation. Conservation Letters 6: 12-20.

Mills, J.H. \& Waite, T.A. (2009) Economic prosperity, biodiversity conservation, and the environmental Kuznets curve. Ecological Economics 68: 2087-2095.

Morse, S. (2017) Relating environmental performance of nation states to income and income inequality. Sustainable Development. Epub ahead of print. DOI:10.1002/sd.1693.

Naidoo, R., Balmford, A., Ferraro, P.J., Polasky, S., Ricketts, T.H. \& Rouget, M. (2006) Integrating economic costs into conservation planning. Trends in Ecology E Evolution 21: 681-687.

Nawrotzki, R.J. (2012) The politics of environmental concern: A cross-national analysis. Organization E Environment 25: 286-307.

Nelson, F., Lindsey, P. \& Balme, G. (2013) Trophy hunting and lion conservation: A question of governance? Oryx 47: 501-509.

Neumayer, E. (2002a) Do democracies exhibit stronger international environmental commitment? A cross-country analysis. Fournal of Peace Research 39: 139-164.

Neumayer, E. (2002b) Does trade openness promote multilateral environmental cooperation? World Economy 25: 815-832.

Oldekop, J.A., Holmes, G., Harris, W.E. \& Evans, K.L. (2016) A global assessment of the social and conservation outcomes of protected areas. Conservation Biology 30: 133-141.

Orubu, C.O. \& Omotor, D.G. (2011) Environmental quality and economic growth: Searching for environmental Kuznets curves for air and water pollutants in Africa. Energy Policy 39: 41784188.

Ostrom, E., Janssen, M.A. \& Anderies, J.M. (2007) Going beyond panaceas. Proceedings of the National Academy of Sciences of the United States of America 104: 15176-15178.

Otto, I.M., Shkaruba, A. \& Kireyeu, V. (2011) The rise of multilevel governance for biodiversity conservation in Belarus. Environment and Planning C-Government and Policy 29: 113-132.

Owen, A.L. \& Videras, J. (2006) Civic cooperation, pro-environment attitudes, and behavioral intentions. Ecological Economics 58: 814829.

Ozturk, I. \& Al-Mulali, U. (2015) Investigating the validity of the environmental Kuznets curve hypothesis in Cambodia. Ecological Indicators 57: 324-330.

Pinker, S. (2011) The Better Angels of Our Nature: Why Violence Has Declined. New York, NY, USA: Viking Books.

Pisano, I. \& Lubell, M. (2017) Environmental behavior in crossnational perspective: A multilevel analysis of 30 countries. Environment and Behavior 49: 31-58.

R Development Core Team (2014) R: A Language and Environment for Statistical Computing. Vienna, Austria: R Foundation for Statistical Computing.

Raymond, C.M. \& Kenter, J.O. (2016) Transcendental values and the valuation and management of ecosystem services. Ecosystem Services 21: 241-257.

Rivera, J. \& Oh, C.H. (2013) Environmental regulations and multinational corporations' foreign market entry investments. Policy Studies fournal 41: 243-272.

Rodrigues, A.S.L., Brooks, T.M., Butchart, S.H.M. et al. (2014) Spatially explicit trends in the global conservation status of vertebrates. PLoS ONE 9: e113934.
Sandbrook, C. (2017) Weak yet strong: The uneven power relations of conservation. Oryx 51: 379-380.

Sapiains, R., Beeton, R.J. \& Walker, I.A. (2016) Individual responses to climate change: Framing effects on pro-environmental behaviors. Fournal of Applied Social Psychology 46: 483-493.

Schleicher, J., Peres, C.A., Amano, T., Llactayo, W. \& LeaderWilliams, N. (2017) Conservation performance of different conservation governance regimes in the Peruvian Amazon. Scientific Reports 7: 11318.

Schuhbauer, A. \& Sumaila, U.R. (2016) Economic viability and small-scale fisheries - A review. Ecological Economics 124: $69-75$.

Schultz, P.W., Gouveia, V.V., Cameron, L.D., Tankha, G., Schmuck, P. \& Franěk, M. (2005) Values and their relationship to environmental concern and conservation behavior. Fournal of Cross-Cultural Psychology 36: 457-475.

Schwartz, S.H. (1992) Universals in the content and structure of values: Theoretical advances and empirical tests in 20 countries. Advances in Experimental Social Psychology 25: 1-65.

Shandra, J.M., Leckband, C., McKinney, L.A. \& London, B., (2009) Ecologically unequal exchange, world polity, and biodiversity loss: A cross-national analysis of threatened mammals. International Fournal of Comparative Sociology 50: 285-310.

Shandra, J.M. (2007) International nongovernmental organizations and deforestation: Good, bad, or irrelevant? Social Science Quarterly 88: 665-689.

Smith, J. \& Wiest, D. (2005) The uneven geography of global civil society: National and global influences on transnational association Social Forces 84: 621-652.

Smith, R.J. \& Walpole, M.J. (2005) Should conservationists pay more attention to corruption? Oryx 39: 251-256.

Smith, R.J., Muir, R.D.J., Walpole, M.J., Balmford, A. \& LeaderWilliams, N. (2003) Governance and the loss of biodiversity Nature 426: $67-70$.

Steg, L. \& Vlek, C. (2009) Encouraging pro-environmental behaviour: An integrative review and research agenda. Fournal of Environmental Psychology 29: 309-317.

Stern, D.I. (2004) The rise and fall of the environmental Kuznets curve. World Development 32: 1419-1439.

Umemiya, C., Rametsteiner, E. \& Kraxner, F. (2010) Quantifying the impacts of the quality of governance on deforestation. Environmental Science E Policy 13: 695-701.

Vincent, J.R., Carson, R.T., DeShazo, J.R., Schwabe, K.A., Ahmad, I., Chong, S.K., Chang, Y.T. \& Potts, M.D. (2014) Tropical countries may be willing to pay more to protect their forests. Proceedings of the National Academy of Sciences of the United States of America 111: 10113-10118.

Waldron, A., Mooers, A., Miller, D.C. et al. (2013) Targeting global conservation funding to limit immediate biodiversity declines. Proceedings of the National Academy of Sciences of the United States of America 110: 12144-12148.

White, L. (1967) The historical roots of our ecologic crisis. Science 155: 1203-1207.

Wolkomir, M., Futreal, M., Woodrum, E. \& Hoban, T. (1997) Substantive religious belief and environmentalism. Social Science Quarterly 78: 96-108.

Wright, S.J., Sanchez-Azofeifa, G.A., Portillo-Quintero, C. \& Davies, D. (2007) Poverty and corruption compromise tropical forest reserves. Ecological Applications 17: 1259-1266.

Zheng, H. \& Cao, S. (2015) Threats to China's biodiversity by contradictions policy. Ambio 44: 23-33. 